\title{
Urotensin-II and its receptor (UT-R) are expressed in rat brain endothelial cells, and urotensin-II via UT-R stimulates angiogenesis in vivo and in vitro
}

\author{
RAFFAELLA SPINAZZI ${ }^{1}$, GIOVANNA ALBERTIN ${ }^{1}$, BEATRICE NICO ${ }^{2}$, DIEGO GUIDOLIN ${ }^{1}$, \\ ROSA DI LIDDO ${ }^{3}$, GIAN PAOLO ROSSI ${ }^{4}$, DOMENICO RIBATTI ${ }^{2}$ and GASTONE G. NUSSDORFER ${ }^{1}$
}

\author{
${ }^{1}$ Department of Human Anatomy and Physiology, Section of Anatomy, University of Padua, I-35121 Padua; ${ }^{2}$ Department \\ of Human Anatomy and Histology, University of Bari, I-70100 Bari; ${ }^{3}$ Interdepartmental Center for the Biology and \\ Medicine of Regeneration, University of Padua, I-45100 Tarcenta (Rovigo); ${ }^{4}$ Department of Clinical and \\ Experimental Medicine, University of Padua, I-35121 Padua, Italy
}

Received July 21, 2006; Accepted September 5, 2006

\begin{abstract}
Urotensin-II (UII), along its receptor UT-R, is widely expressed in the cardiovascular system, where it exerts regulatory actions under both physiological and pathological conditions. Real-time PCR and immunocytochemistry demonstrated the expression of UII and UT-R as mRNA and protein in rat neuromicrovascular endothelial cells (NECs). UII did not affect the proliferation rate of cultured NECs, but exerted a strong angiogenic action in both an in vitro assay on Matrigel and an in vivo assay on chorioallantoic membrane. The angiogenic effect of UII was similar to that of FGF-2, and was abolished by the UT-R antagonist Palosuran. Collectively, our findings allow us to include UII in the group of cytokines (e.g. endothelin-1 and adrenomedullin), which are expressed in endothelial cells and exert a pro-angiogenic effect acting in an autocrine-paracrine manner.
\end{abstract}

\section{Introduction}

Urotensin-II (UII) is a cyclic 11- (human) or 15-amino acid peptide (rodent), originally isolated from fish urophysis (1), which exerts a potent systemic vasoconstrictor and hypertensive effect $(2,3)$. UII has been identified as an endogenous ligand of the orphan $\mathrm{G}$ protein-coupled receptor (GPR) $14(2,4,5)$, that has been renamed urotensin receptor (UT-R) (6).

Correspondence to: Professor G.G. Nussdorfer, Department of Human Anatomy and Physiology, Section of Anatomy, University of Padua, Via Gabelli 65, I-35121 Padua, Italy

E-mail: gastone.nusdorfer@unipd.it

Key words: urotensin-II, urotensin receptors, Palosuran, angiogenesis, endothelial cells, rat
UII and UT-R are widely expressed in the heart and large arteries (7-11), and many lines of evidence lead us to conclude that UII plays a role in the physiology and pathophysiology of the cardiovascular system (12-14). UII has also been reported to exert a strong mitogenic action on many cell phenotypes, and the expression of UII and UT-R has been demonstrated in several tumor-derived cell lines (11).

The cardiovascular distribution and the potential tumor growth promoting action of UII prompted us to examine whether UII and UT-R are expressed in endothelial cells (EC) and can affect angiogenesis in vivo and in vitro.

\section{Materials and methods}

Animals and reagents. Male adult Sprague-Dawley rats were purchased from Charles-River (Como, Italy), and the experiment protocol was approved by the local Ethics Committee for Animal Studies. Rat UII was obtained from Neosystem Laboratoires (Strasbourg, France), EC growth medium MV2 from Promo Cell (Heidelberg, Germany), Matrigel $^{\circledR}$ from Becton Dickinson Labware (Bedford, MA) and human recombinant fibroblast growth factor (FGF)-2 from R\&D Systems (Abingdon, UK). Goat anti-rat UT-R (E18, sc-10194) and UII antibodies (C-19, sc-21095) were purchased from Santa Cruz Biotechnology (Santa Cruz, CA), and rabbit anti-goat $\mathrm{Cy} 2-$ and $\mathrm{Cy} 3$-conjugated secondary antibodies from Chemicon (Temecula, CA). Fetal calf serum (FCS), bovine serum albumin (BSA), phosphate-buffered saline (PBS), 5'-bromo-2'-deoxyuridine (BrdU), 4',6'diamine-2'-phenilindole (DAPI), and all other chemicals and laboratory reagents were provided by Sigma-Aldrich Corp. (St. Louis, MO). The UT-R antagonist (UT-RA) Palosuran (ACT-058362) (15) was a gift from Dr M. Clozel (Actelion Pharmaceutical Ltd., Allschwil, Switzerland).

Neuromicrovascular EC (NEC) culture. Rats were decapitated and their brains were promptly removed. NECs were isolated from the brains, according to Abbot et al (16), and cultured and purified by immunoseparation, as 
previously described $(17,18)$. In all experiments, cultures from the 2 nd to the 4 th passage were used.

Real-time RT-PCR. NECs from the 2nd passage were harvested, and total RNA was extracted, purified and reverse transcribed to cDNA $(19,21)$. Real-time PCR was carried out in an I-Cycler iQ detection system (BioRad Laboratories, Milan, Italy), as detailed previously (22-24), using the following primers: i) rat UII: sense-131-5', 5'-AGCTTCCAG TGCTTGAGGAA-3' and antisense-314-3', 5'-GAATCTTGC CCAGTGAGAGC-3' (NM_019160, bp 183); and ii) rat UT-R: sense-80-5', 5'-ACTCCAACGTGTCCCTCAAC-3' and antisense-317-3', 5'-AAGGGAATGCTCAGCAGGTA-3' (NM_020537, bp 237). The PCR program included a denaturation step at $95^{\circ} \mathrm{C}$ for $3 \mathrm{~min}, 35$ cycles of two amplification steps at $95^{\circ} \mathrm{C}$ for $15 \mathrm{sec}$ and annealing at $60^{\circ} \mathrm{C}$ for $30 \mathrm{sec}$, and melting curve at $60-90^{\circ} \mathrm{C}$ with a heating rate of $0.5^{\circ} \mathrm{C} / 10 \mathrm{sec}$. The specificity of amplification was tested at the end of each run by melting curve analysis, using the ICycler software 3.0. The specificity of the PCR was further verified by sequencing analysis, as previously detailed (25).

Immunocytochemistry (ICC). NECs from the 2nd passage were seeded on fibronectin-coated cover slides on a 24-well plate, fixed in $4 \%$ paraformaldehyde in PBS, treated with $0.1 \%$ Triton $\mathrm{X}-100$ in PBS, and incubated with the blocking solution (3\% BSA in PBS) for $60 \mathrm{~min}$. The blocking solution was removed, and NECs were incubated overnight with goat anti-UII or anti-UT-R primary antibodies (1:50 dilution) at $4^{\circ} \mathrm{C}$. Cells were washed, and incubated with anti-goat $\mathrm{Cy} 3-$ (red fluorescence) or Cy2-conjugated secondary antibodies (green fluorescence) for $60 \mathrm{~min}$ at room temperature to evidence UII- and UT-R-labeling, respectively. After repeated washing, cells were counterstained with the nuclear dye DAPI. Negative controls were carried out by similarly treating NECs, but omitting the primary antibody (26). Specimens were observed by a Leitz fluorescence microscope.

Cell proliferation assay. NECs from the 3rd passage were seeded $\left(1.5 \times 10^{4}\right.$ cells $\left./ \mathrm{cm}^{2}\right)$ into a 96 -well plate, and cultured in MV2 medium, with $1 \%$ amphotericin/B-gentamycin, 5\% FCS, $0.2 \mu \mathrm{g} / \mathrm{ml}$ hydrocortisone and $1 \mu \mathrm{g} / \mathrm{ml}$ ascorbic acid (basal medium). After $24 \mathrm{~h}$ of incubation, the culture medium was replaced with a fresh one containing or not containing FGF-2 (50 ng/ml), and UII $\left(10^{-7} \mathrm{M}\right)$ and/or Palosuran $\left(10^{-6} \mathrm{M}\right)$, and incubated at $37^{\circ} \mathrm{C}$. After $6 \mathrm{~h}$ of incubation, $\operatorname{BrdU}\left(10^{-5} \mathrm{M}\right)$ was added (17), and NECs were incubated for a further $18 \mathrm{~h}$. The proliferation rate was estimated by the cell proliferation kit of Amersham Pharmacia (Aylesbury, UK). Results were expressed as percent change from baseline and were the mean \pm SD of 6 separate experiments.

In vitro angiogenesis assay. Matrigel was thawed on ice overnight, and spread evenly (50 $\mu 1)$ over each well of a 24well plate. The plates were incubated for $30 \mathrm{~min}$ at $37^{\circ} \mathrm{C}$ to allow Matrigel to gel, and NECs from the 4th passage were seeded $\left(2.5 \times 10^{4}\right.$ cells $\left./ \mathrm{cm}^{2}\right)$ and cultured in basal medium, containing or not containing i) UII $\left(10^{-7} \mathrm{M}\right)$ and/or Palosuran $\left(10^{-6} \mathrm{M}\right)$; and ii) FGF-2 $(50 \mathrm{ng} / \mathrm{ml})$ and/or UT-RA $\left(10^{-6} \mathrm{M}\right)$. After $18 \mathrm{~h}$ of incubation at $37^{\circ} \mathrm{C}$, cultures were photographed

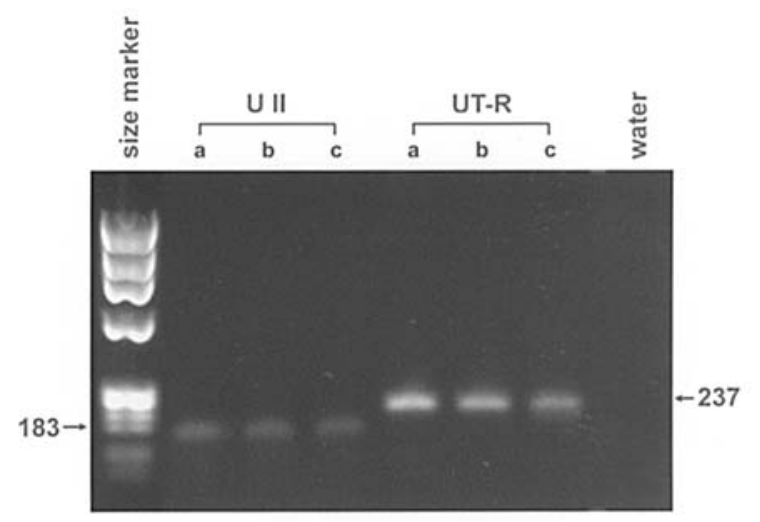

Figure 1. Ethidium bromide-stained 2\% agarose gel electrophoresis showing cDNA amplified with rat UII and UT-R specific primers from RNA of three exemplary cultured NECs. The first lane was loaded with Roche marker VIII. No amplification with water instead of RNA is shown as negative control.
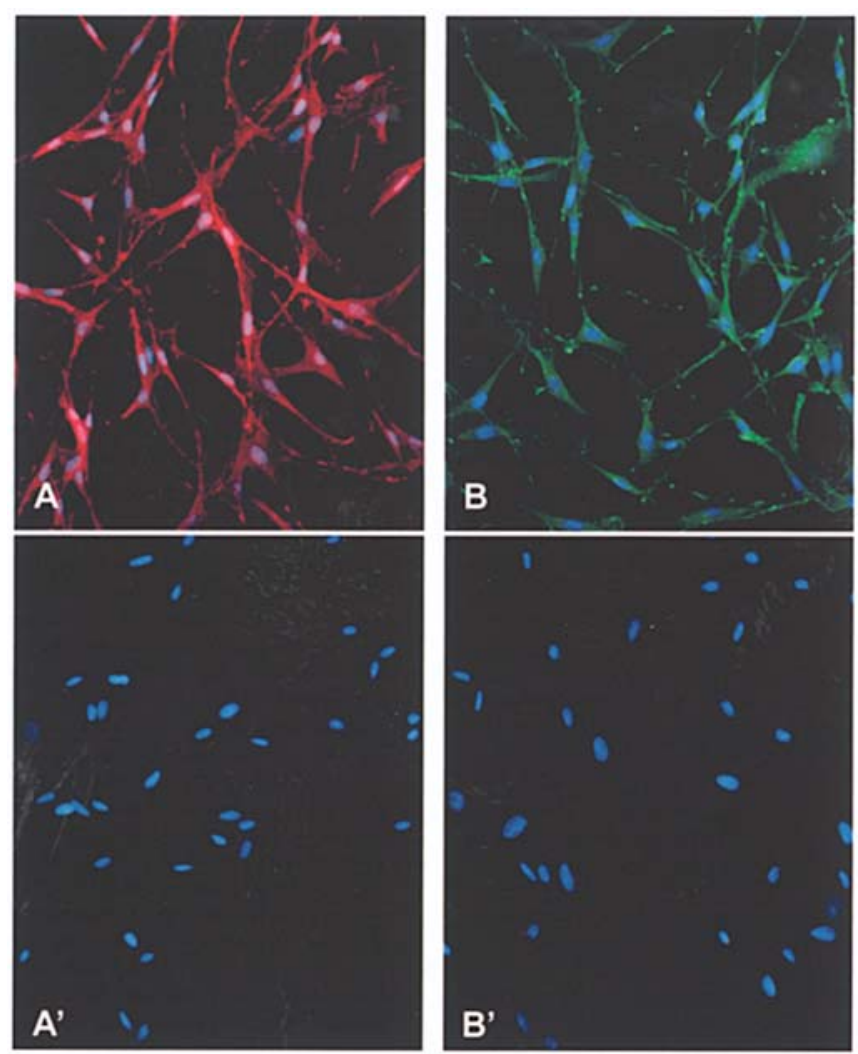

Figure 2. ICC demonstration of UII (red immunofluorescence) (A) and UT-R (green immunofluorescence) (B) in NECs. The respective negative controls are shown in the lower panels ( $\mathrm{A}^{\prime}$ and $\left.\mathrm{B}^{\prime}\right)$. DAPI-stained nuclei appear as blue structures. Magnification x180.

and phase contrast images were recorded, using a digital camera (DG 200; Leica imaging system, Cambridge, UK) connected to a Laborlux S microscope (Leitz, Wetzlar, Germany) and saved as TIFF files. Image analysis was carried out using the Leica Qwin software, as previously detailed (27). Values were expressed as difference $( \pm \Delta)$ from baseline values, and were the means \pm SD of 4 separate experiments. 


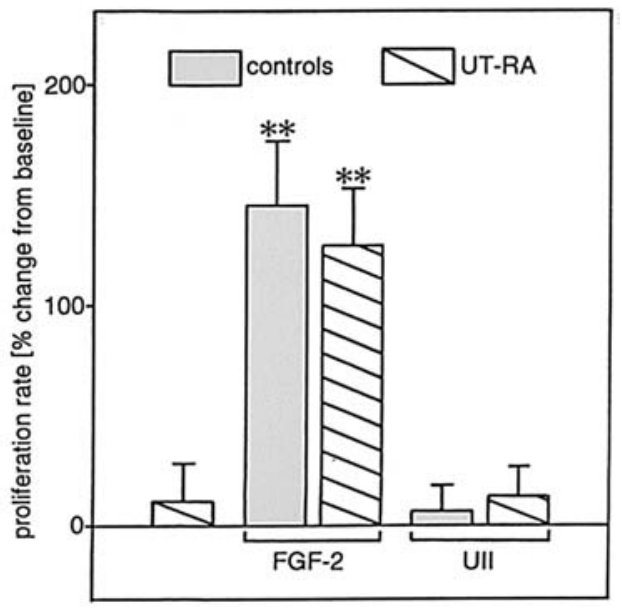

Figure 3. Effects of FGF-2 $(50 \mathrm{ng} / \mathrm{ml})$, UII $\left(10^{-7} \mathrm{M}\right)$ and the UT-RA Palosuran $\left(10^{-6} \mathrm{M}\right)$ on the proliferation rate of cultured NECs. Bars are means $\pm \mathrm{SD}$ of six separate experiments. ${ }^{* *} \mathrm{P}<0.01$ from baseline.
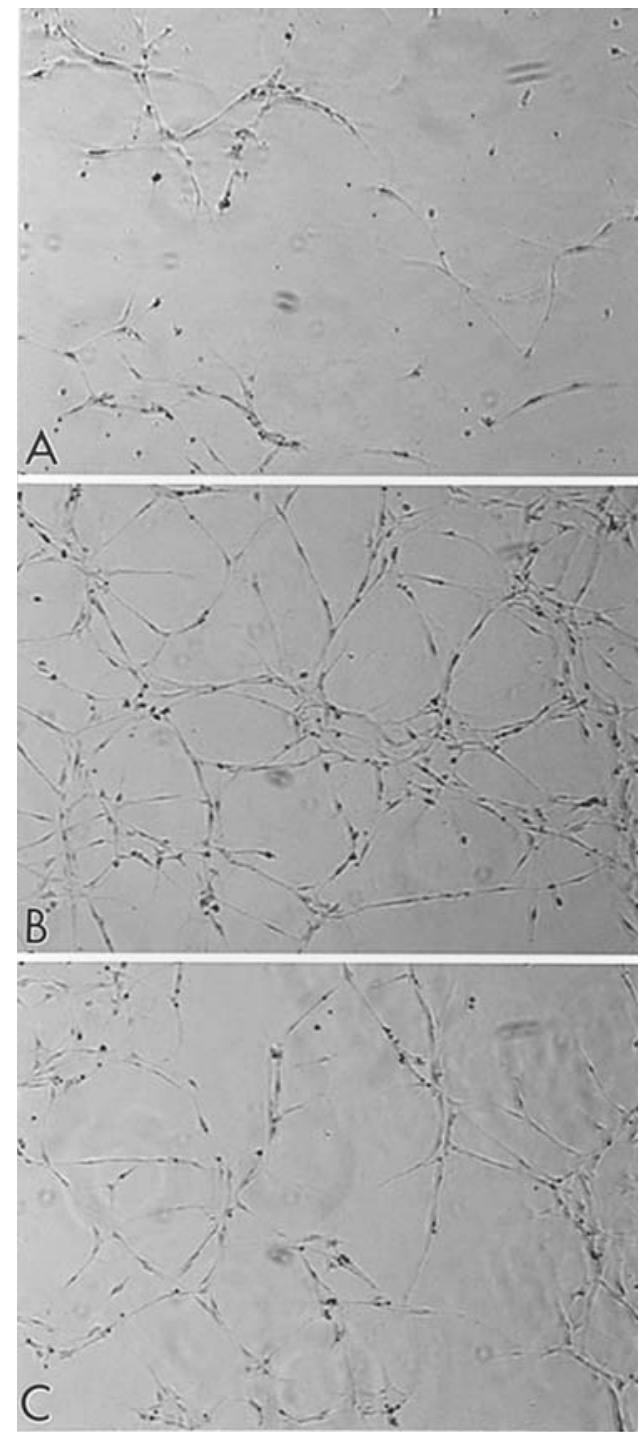

Figure 4. Phase contrast micrographs illustrating the arrangement of NECs into a meshwork of capillary-like tubular structures when cultured on Matrigel for $24 \mathrm{~h}(\mathrm{~A})$. UII $\left(10^{-7} \mathrm{M}\right)$ increases the density of the meshwork (B), and the UT-RA Palosuran $\left(10^{-6} \mathrm{M}\right)$ counteracts this effect $(\mathrm{C})$. Magnification x60.
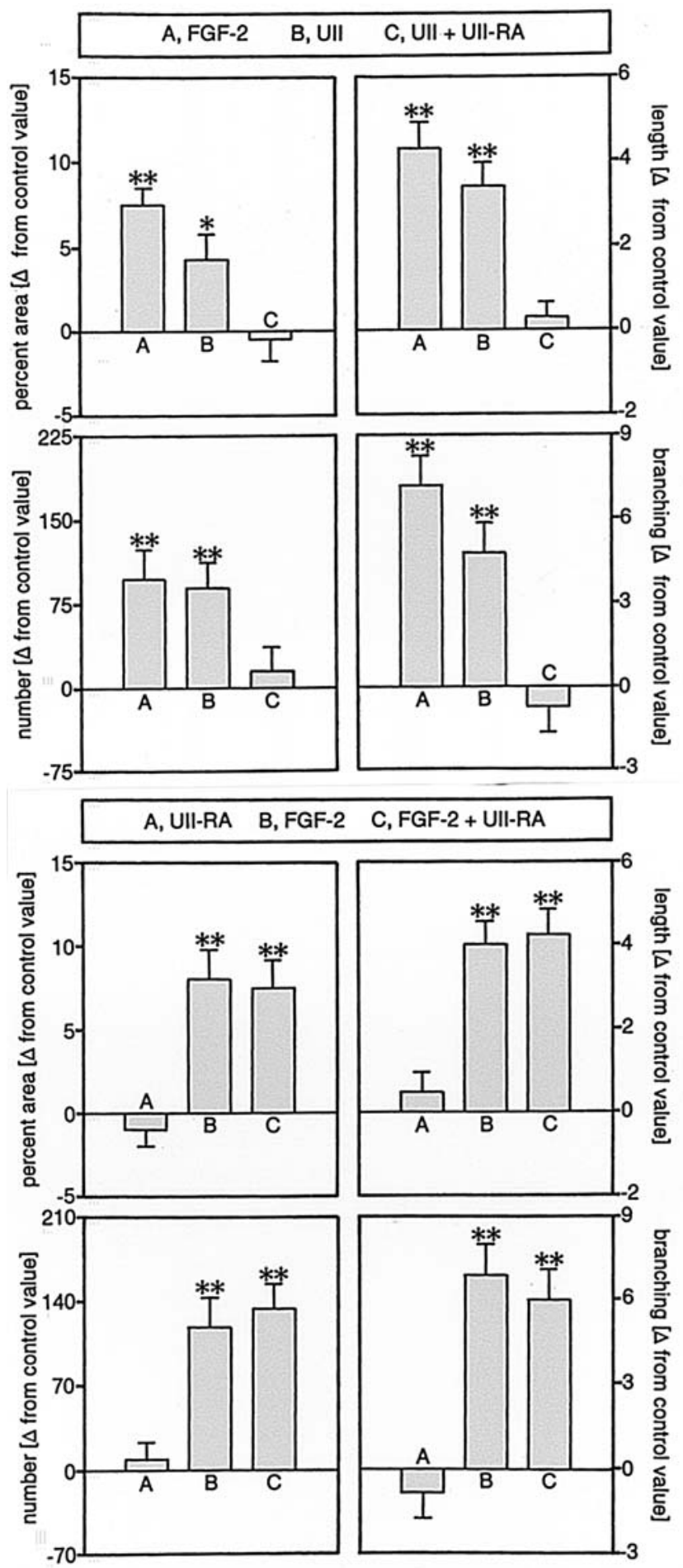

Figure 5. Quantitative analysis of the effects of FGF-2 (50 ng/ml), UII $\left(10^{-7} \mathrm{M}\right)$ and the UT-RA Palosuran $\left(10^{-6} \mathrm{M}\right)$ on the dimensional [percent area covered by NECs and total length per field (length)] and topological parameters [number of meshes per field (number) and number of branching points per field (branching)] of the NEC meshwork. Bars are means \pm SD of four separate experiments. ${ }^{*} \mathrm{P}<0.05$ and ${ }^{* *} \mathrm{P}<0.01$ from control value.

In vivo angiogenesis assay. Chorioallantoic membrane (CAM) assay was carried out as previously described (28). Briefly, fertilized white-leghorn chicken eggs (10 per group) were incubated at $37^{\circ} \mathrm{C}$ under constant humidity. On incubation day 3 , a square window was opened in the shell to detach the developing CAM after removal of $2-3 \mathrm{ml}$ of albumen. The 


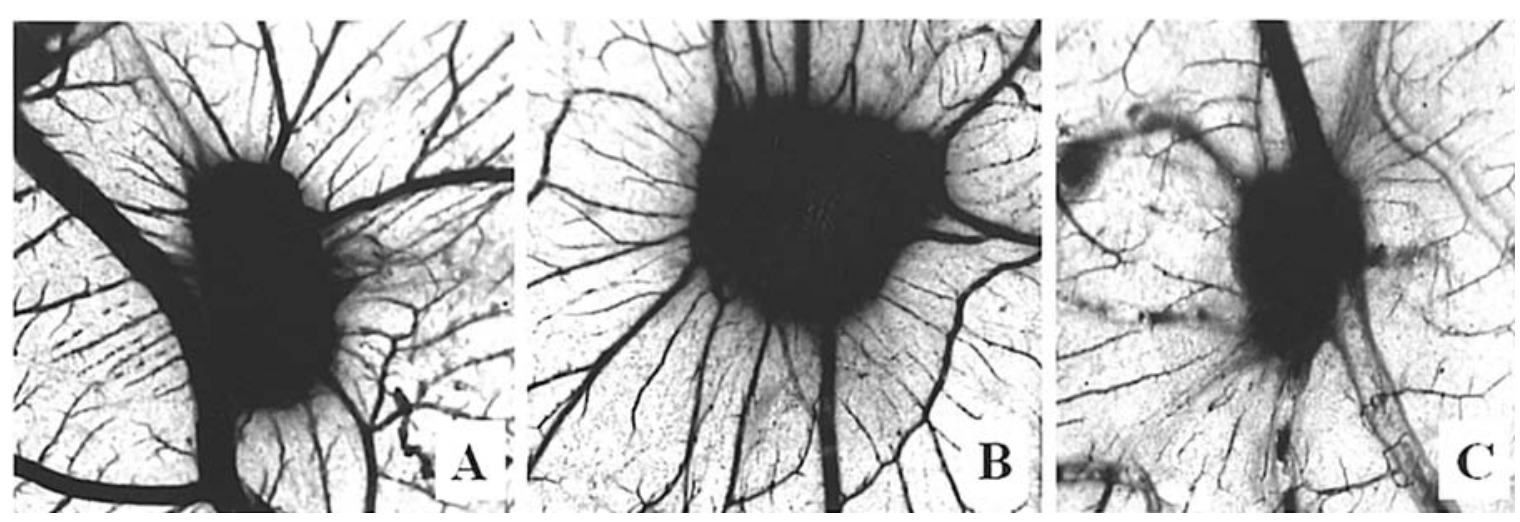

Figure 6. Macroscopic pictures of gelatin sponges soaked with UII (A), FGF-2 (B) and UII plus the UT-RA Palosuran (C), implanted onto the chick embryo chorioallantoic membrane on day 12 of incubation. Note that in A and B numerous allantoic vessels are radially arranged toward the implants, while in $\mathrm{C}$ few vessels are recognizable. Magnifications x36.

window was sealed with a glass and eggs were returned to the incubator. On incubation day 8 , a $1 \mathrm{~mm}^{3}$ sterilized gelatin sponge (Gelfoam Upjohn, Kalamazoo, MI) was placed on the top of the growing CAM. Sponges were loaded with $1 \mu 1$ vehicle (PBS), containing or not containing UII $\left(10^{-7} \mathrm{M}\right)$, UII plus UT-RA $\left(10^{-6} \mathrm{M}\right)$, and $500 \mu \mathrm{g}$ FGF-2. CAM were examined daily until day 12 and photographed in ovo with a stereomicroscope equipped with a MC63 camera system (Zeiss, Oberkochen, Germany). On day 12, blood vessels entering the sponge within the focal plane of the CAM were counted by two observers in a double-blind fashion at a magnification of $\mathrm{x} 50$, and mean values $\pm \mathrm{SD}$ were determined.

Statistical analysis. The statistical comparison of results was performed by ANOVA, followed by Student's t-test for unpaired data.

\section{Results}

RT-PCR revealed a low expression of UII mRNA and an elevated expression of UT-R mRNA in all NEC specimens examined (Fig. 1). The melting curve analysis showed clean defined peaks at temperatures of 91 and $90^{\circ} \mathrm{C}$ for UII and UT-R genes, respectively, thus ruling out the amplification of non-specific products. ICC showed intense immunostaining for both UII and UT-R in NECs (Fig. 2).

FGF-2 significantly raised the proliferation rate of cultured NECs, while UII or Palosuran were ineffective (Fig. 3). After seeding on Matrigel, NECs spread and alligned with each other to form branching anastomosing tubes with multicentric junctions that gave rise within $24 \mathrm{~h}$ to a meshwork of capillary-like structures (Fig. 4A). UII $\left(10^{-7} \mathrm{M}\right)$ increased the density of the meshwork, and Palosuran counteracted this effect (Fig. 4B and C). Image analysis confirmed these observations, showing that UII $\left(10^{-7} \mathrm{M}\right)$, like FGF-2, significantly increased both dimensional (percent area covered by NECs and total length of the network per field) and topological parameters (number of meshes and branching points per field) of the capillary-like meshwork, and Palosuran annulled this effect (Fig. 5). The UT-RA Palosuran was per se ineffective, and did not alter the pro-angiogenic action of FGF-2 (Fig. 5). UII $\left(10^{-7} \mathrm{M}\right)$, added to the CAM, induced a

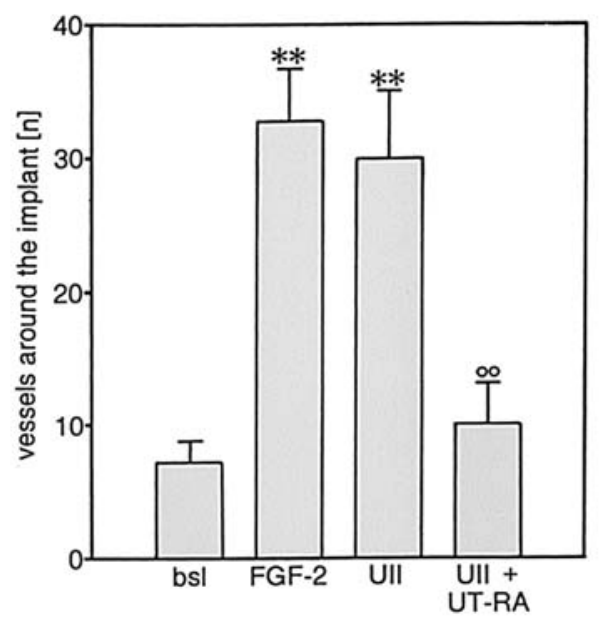

Figure 7. Quantitative analysis of the effects of FGF-2 $(50 \mathrm{ng} / \mathrm{ml}), \mathrm{UII}\left(10^{-7} \mathrm{M}\right)$ and the UT-RA Palosuran $\left(10^{-6} \mathrm{M}\right)$ on the angiogenesis in the CAM. Bars are means $\pm \mathrm{SD}$ of eight separate experiments. ${ }^{* *} \mathrm{P}<0.01$ from baseline value; ${ }^{\circ} \mathrm{P}<0.01$ from $\mathrm{FGF}-2$ and UII values.

strong angiogenic response, comparable to that of FGF-2. When Palosuran was added together with UII, a significant inhibition of the angiogenic response was observed in $70 \%$ of the treated embryos (Figs. 6 and 7).

\section{Discussion}

Our angiogenic assays provide unequivocal evidence that UII exerts a potent angiogenic action in vitro and in vivo, comparable to that of one of the main classic angiogenic cytokines, FGF-2 (29). This effect of UII appears to be selectively mediated by UT-R, because it is annulled by the specific UT-RA Palosuran (15). Palosuran neither per se affects basal angiogenesis nor alters the pro-angiogenic action of FGF-2, thereby ruling out the possibility of its nonspecific toxic effect. Remarkably, the pro-angiogenic action of UII, in contrast with that of FGF-2, is not associated with a proliferogenic effect on NECs. This would suggest that different mechanisms underlie the in vitro actions of these two cytokines. 
The present coupled RT-PCR and ICC findings indicating that not only UT-R, but also UII is expressed in NECs, are consistent with a possible autocrine-paracrine mechanism of action. In this regard, it is to be noted that there is evidence of an autocrine-paracrine action of UII in the adrenal glands, where this peptide negatively modulates in vitro glucocorticoid secretion (30). Hence, our study suggests that UII may be included in the group of non-classic pro-angiogenic cytokines expressed in ECs, which, in addition to regulating cardiovascular function, also exert a tumor growth-promoting action.

The main members of this cytokine family are endothelin-1 (31) and adrenomedullin (32), which are both known to be potent angiogenic peptides $(33,34)$ and are thought to be the potential targets of antineoplastic therapies $(35,36)$. Of interest, the putative UT-RA SB-710411 (37) was not found to block the in vitro and in vivo angiogenic action of UII (data not shown), suggesting that Palosuran may be an elective drug of potential relevance in anti-angiogenic therapeutic strategies.

\section{References}

1. Pearson D, Shively JE, Clark BR, Geschwind II, Barkley M, Nishioka RS and Bern HA: Urotensin II: a somatostatin-like peptide in the caudal neurosecretory system of fishes. Proc Natl Acad Sci USA 77: 5021-5024, 1980.

2. Ames RS, Sarau HM, Chambers JK, Willette RN, Aiyar NV, Romanic AM, Louden CS, Foley JJ, Sauermelch CF, Coatney RW, Ao Z, Disa J, Holmes SD, Stadel JM, Martin JD, Liu WS, Glover GI, Wilson S, McNulty DE, Ellis CE, Elshourbagy NA, Shabon U, Trill JJ, Hay DWP, Ohlstein EM, Bergsma DJ and Douglas SA: Human urotensin-II is a potent vasoconstrictor and agonist for the orphan receptor GPR 14. Nature 401: 282-286, 1999.

3. Douglas SA and Ohlstein EH: Human urotensin-II, the most potent mammalian vasoconstrictor identified to date, as therapeutic target for the management of cardiovascular disease. Trends Cardiovasc Med 10: 229-237, 2000.

4. Liu Q, Pong SS, Zeng Z, Zhang Q, Howard AD, Williams DR, Davidoff M, Wang R, Austin CP, McDonald TP, Bai C, George SR, Evans JF and Caskey CT: Identification of urotensin II as the endogenous ligand for the orphan G-protein coupled receptor GPR 14. Biochem Biophys Res Commun 266: 174-178, 1999.

5. Mori M, Sugo T, Abe M, Shimomura Y, Kurihara M, Kitada C, Kikuchi K, Shintari Y, Kurokawa T, Onda H, Nishimura O and Fujino M: Urotensin II is the endogenous ligand of a G-protein coupled orphan receptor, SENR (GPR14). Biochem Biophys Res Commun 265: 123-129, 1999.

6. Davenport AP and Maguire JJ: Urotensin II: fish neuropeptide catches orphan receptor. Trends Pharmacol Sci 21: 80-92, 2000.

7. Nothacker HP, Wang Z, McNeill AM, Saito Y, Marten S, O'Dowd B, Duckles SP and Civelli O: Identification of the natural ligand of an orphan G-protein coupled receptor involved in the regulation of vasoconstriction. Nat Cell Biol 1: 383-385, 1999.

8. Maguire JJ, Kuc RE and Davenport AP: Orphan-receptor ligand human urotensin II: receptor localization in human tissues and comparison of vasoconstrictor responses with endothelin-1. Br J Pharmacol 131: 441-446, 2000.

9. Matsushita M, Shichiri M, Imai T, Iwashina M, Tanaka H, Takasu N and Hirata Y: Co-expression of urotensin II and its receptor (GPR14) in human cardiovascular and renal tissues. J Hypertens 19: 2185-2190, 2001.

10. Totsune K, Takahashi K, Arihara Z, Sone M, Satoh F, Ito S, Kimura Y, Sasano H and Murakami O: Role of urotensin II in patients on dialysis. Lancet 358: 810-811, 2001.

11. Yoshimoto T, Matsushita M and Hirata Y: Role of urotensin II in peripheral tissue as an autocrine/paracrine growth factor. Peptides 25: 1775-1781, 2004

12. Cheung BMY, Leung R, Man YB and Wong LYF: Plasma concentration of urotensin II is raised in hypertension. J Hypertens 22: 1341-1344, 2004.
13. Russell FD and Molenaar P: Cardiovascular actions of human urotensin II: considerations for hypertension. Naunyn Schmiedebergs Arch Pharmacol 369: 271-273, 2004.

14. Douglas SA, Tayara L, Ohlstein EH, Halawa N and Giaid A: Congestive heart failure and expression of myocardial urotensin II. Lancet 359: 1990-1997, 2002.

15. Clozel M, Binkert C, Birker-Robaczewska M, Boukhadra C, Ding SS, Fischli W, Hess P, Mathys B, Morrison K, Müller C, Müller C, Nayler O, Qiu C, Rey M, Scherz NW, Velker J, Weller T, Xi JF and Ziltener P: Pharmacology of the urotensinII receptor antagonist Palosuran (ACT-058362; 1-[2-(4-benzyl4-hydroxy-piperidin-1-yl)-ethyl]-3-(2-methyl-quinolin-4-yl)urea sulfate salt): first demonstration of a pathophysiological role of the urotensin system. J Pharmacol Exp Ther 311: 204-212, 2004.

16. Abbott NJ, Hughes CCW, Revest PA and Greenwood J: Development and characterization of a rat brain capillary endothelial culture: towards an in vitro blood-brain barrier. J Cell Sci 103: 23-37, 1992.

17. Baiguera S, Conconi MT, Guidolin D, Mazzocchi G, Malendowicz LK, Parnigotto PP, Spinazzi R and Nussdorfer GG: Ghrelin inhibits in vitro angiogenic activity of rat brain microvascular endothelial cells. Int J Mol Med 14: 849-854, 2004.

18. Folin M, Baiguera S, Tommasini M, Guidolin D, Conconi MT, De Carlo E, Nussdorfer GG and Parnigotto PP: Effects of $\beta$-amyloid on rat neuromicrovascular endothelial cells cultured in vitro. Int J Mol Med 15: 929-935, 2005.

19. Albertin G, Carraro G and Nussdorfer GG: Human adrenomedullin gene silencing by short interfering RNAs: A preliminary study. Int J Mol Med 15: 579-583, 2005.

20. Andreis PG, Rucinski M, Neri G, Conconi MT, Petrelli L, Parnigotto PP, Malendowicz LK and Nussdorfer GG: Neuropeptides B and W enhance the growth of human adrenocortical carcinoma-derived NCI-H295 cells by exerting MAPK p42/p44-mediated proliferogenic and antiapoptotic effects. Int J Mol Med 16: 1021-1028, 2005.

21. Rucinski M, Andreis PG, Ziolkowska A, Nussdorfer GG and Malendowicz LK: Differential expression and function of beacon in the rat adrenal cortex and medulla. Int J Mol Med 16: $35-40,2005$.

22. Albertin G, Carraro G, Petrelli L, Guidolin D, Neri G and Nussdorfer GG: Endothelin-1 and adrenomedullin enhance the growth of human adrenocortical carcinoma-derived SW-13 cell line by stimulating proliferation and inhibiting apoptosis. Int $\mathbf{J}$ Mol Med 15: 469-474, 2005.

23. Albertin G, Rucinski M, Carraro G, Forneris M, Andreis PG, Malendowicz LK and Nussdorfer GG: Adrenomedullin and vascular endothelium growth factor genes are overexpressed in the regenerating rat adrenal cortex, and AM and VEGF reciprocally enhance their mRNA expression in cultured rat adrenocortical cells. Int J Mol Med 16: 431-435, 2005.

24. Spinazzi R, Ziolkowska A, Neri G, Nowak M, Rebuffat P, Nussdorfer GG, Andreis PG and Malendowicz LK: Orexins modulate the growth of cultured rat adrenocortical cell, acting through type 1 and type 2 receptors coupled to the MAPK $\mathrm{p} 42 / \mathrm{p} 44-$ and $\mathrm{p} 38$-dependent cascades. Int J Mol Med 15: 847-852, 2005.

25. Rossi GP, Sticchi D, Giuliani L, Bernante P, Zavattiero S, Pessina AC and Nussdorfer GG: Adiponectin receptor expression in the human adrenal cortex and aldosterone-producing adenomas. Int J Mol Med 17: 975-980, 2006.

26. Belloni AS, Guidolin D, Salmaso R, Bova S, Rossi GP and Nussdorfer GG: Adrenomedullin, ANP and BNP are colocalized in a subset of endocrine cells in the rat heart. Int $\mathrm{J}$ Mol Med 15: 567-571, 2005.

27. Ribatti D, Guidolin D, Conconi MT, Nico B, Baiguera S, Parnigotto PP, Vacca A and Nussdorfer GG: Vinblastine inhibits the angiogenic response induced by adrenomedullin in vitro and in vivo. Oncogene 22: 6458-6461, 2003.

28. Ribatti D, Gualandris A, Bastaki M, Vacca A, Iurlaro M, Roncali L and Presta M: New model for the study of angiogenesis and antiangiogenesis in the chick embryo chorioallantoic membrane: the gelatin sponge/chorioallantoic membrane assay. J Vasc Res 34: 455-463, 1997.

29. Ribatti D, Vacca A and Presta M: The discovery of angiogenic factors: a historical review. Gen Pharmacol 35: 227-231, 2002.

30. Albertin G, Casale V, Ziolkowska A, Spinazzi R, Malendowicz LK, Rossi GP and Nussdorfer GG: Urotensin-II and UII-receptor expression and function in the rat adrenal cortex. Int J Mol Med 17: 1111-1115, 2006. 
31. Kedzierski RM and Yanagisawa M: Endothelin system: the double-edged sword in health and disease. Annu Rev Pharmacol 41: 851-876, 2001

32. Lopez J and Martinez A: Cell and molecular biology of the multifunctional peptide adrenomedullin. Int Rev Cytol 221: 1-92, 2002.

33. Salani D, Taraboletti G, Rosanò L, Di Castro V, Borsotti P, Giavazzi R and Bagnato A: Endothelin-1 induces an angiogenic phenotype in cultured endothelial cells and stimulates neovascularization in vivo. Am J Pathol 157: 1703-1711, 2000.

34. Nagaya N, Mori H, Murakami S, Kangawa K and Kitamura S: Adrenomedullin: angiogenesis and gene therapy. Am J Physiol 288: 1432-1437, 2005 .
35. Bagnato A and Spinella F: Emerging role of endothelin-1 in tumor angiogenesis. Trends Endocrinol Metab 14: 44-50, 2002.

36. Nikitenko LL, Fox SB, Kehoe S, Rees MCP and Bicknell R: Adrenomedullin and tumor angiogenesis. Br J Cancer 94: 1-7, 2006.

37. Behm DJ, Herold CL, Ohlstein EH, Knight SD, Dhanak D and Douglas SA: Pharmacological characterization of SB-710411 (Cpa-c[D-Cys-Pal-D-Trp-Lys-Val-Cys]-Cpa-amide), a novel peptidic urotensin-II receptor antagonist. Br J Pharmacol 137: 449-458, 2002. 